\title{
XXX lat kształcenia kadr kultury fizycznej w Łodzi - kalendarium dokonań
}

\section{XXX years of education of physical education teachers in Łódź - a calendar of achievements}

The article presents the issues of education of physical education specialists in Łódź. It is an attempt to systematize the achievements in the field of education of physical education teachers, trainers and sports coaches in the academic environment of Łódź.

It contains the most important information relating to the origin of access to education at this department, important moments, facts, events decisive for the existence and further education of specialists of physical culture in Łódź. It presents the profiles of the creators of this initiative and important figures in its history.

A crucial part of the study are the lists of graduates (Physical and Health Education and Physical Culture and Health), graduating in successive years at the Faculty of Educational Sciences of the University of Łódź.

\section{Wprowadzenie}

Kształcenie kadr dla wychowania fizycznego i sportu oraz pozostałych dziedzin kultury fizycznej ma stosunkowo niedługą historię, liczącą niewiele ponad sto lat. Pojawiło się w odpowiedzi na realizację postulatu równoległego - do pozostałych obszarów osobowości - kształtowania fizycznego młodzieży, jaką było zorganizowanie zajęć fizycznych w placówkach szkolnych, w odradzającej się po latach niewoli Polsce.

Samo kształcenie fizyczne w edukacji ma historię o wiele dłuższą i pojawia się choćby w ateńskiej kalokagatii. Najważniejszy, drugi etap edukacji zawierał 
ćwiczenia gimnastyczne odbywane w palestrze (boisku do ćwiczeń) pod nadzorem pedotryby ${ }^{1}$. Był to odpowiednik dzisiejszego instruktora ćwiczeń fizycznych, który - według Galena - „wskazuje praktycznie, jak te ćwiczenia powinny i mogą przebiegać”, w odróżnieniu od gimnasty, który „zna działanie wszystkich ćwiczeń i zaleca je różnym ludziom według tego co uważa za korzystne dla zdrowia i dobrego samopoczucia" (Kowieska, 1994, s. 136-138). Gimnasta to współczesny, wysokiej klasy specjalista władający biegle rozległą wiedzą „gimnastyczną" (według Galena "Gimnastyka jest wiedzą o działaniu wszystkich ćwiczeń”), a więc wiedzą z obszaru nauk biologicznych (anatomii i fizjologii człowieka) oraz psychopedagogicznych, a także wiedzą o różnych dziedzinach sportu, pedotryba zaś to instruktor „zaledwie” prowadzący zajęcia (Ławniczak, 2010).

Kształcenie fizyczne w kształceniu ogólnym nigdy już nie miało takiej rangi jak w antycznej Grecji. Niemniej jednak zawitało do szkół w XX wieku jako przedmiot szkolny stopniowo wprowadzany na poszczególnych etapach edukacji w wymiarze najczęściej dwóch godzin tygodniowo i - zgodnie z deklaracjami i zapisami - na równych, z pozostałymi przedmiotami, zasadach. Do jego realizacji zatrudnieni zostali specjaliści w dziedzinie wspomagania i kształtowania fizycznego rozwoju młodego człowieka.

Bodaj pierwszym, który zwrócił uwagę na konieczność przygotowania specjalistów dla takich zajęć, był polski uczony, lekarz, filozof Sebastian Petrycy (1554-1626). W wydanej w 1605 roku Polityce Arystotelesowej sformułował zaskakującą - jak na ówczesne czasy - uwagę odnoszącą się do specjalnie w tym celu powołanych (i zapewne przygotowanych) osób: „Takie ćwiczenia cielesne dzieci powinny być kierowane przez kogoś, kto by pilnował tego, aby młodzież nie forsowała się zbytnio, zwracał uwagę na wiek ćwiczących, rodzaj i układ ćwiczeń, dietę i wreszcie cel, dla którego takie ćwiczenia są podejmowane" (Hądzelek, Wroczyński, 1968, s. 268). Biorąc pod uwagę realia epoki, powszechność systemu szkolnego, powyższe stwierdzenie należy traktować jako wspaniały pomnik wielkości myśli w obszarze kultury fizycznej renesansowego uczonego.

$Z$ realnym przygotowywaniem (kształceniem) osób do prowadzenia zajęć fizycznych spotkamy się dopiero XIX wieku. Najwcześniej, bo w 1813 roku, powstał w Sztokholmie Centralny Królewski Instytut Gimnastyczny - pierwsza w świecie uczelnia kształcąca nauczycieli gimnastyki.

W Polsce największe zaplecze kadrowe do prowadzenia zajęć fizycznych z młodzieżą stanowili członkowie, powstałego w 1867 roku we Lwowie, Towarzystwa

1 Pierwszy etap edukacji od 8 do 13/14 roku życia poświęcony był nauce czytania, pisania, rachunków (pod kierunkiem gramatysty) i przyswajaniu pamięciowemu fragmentów utworów poetyckich lliady i Odysei dla zapoznania z ojczysta historią i geografią, także nauka gry na lutni, śpiewu i deklamacji, prowadzona przez lutnistę (kitarystę). Kolejny etap edukacji zawierał poza gimnastyką przygotowywanie do uczestnictwa w życiu społeczno-politycznym (dyskusje z filozofami, urzędnikami, politykami). Z czasem (w okresie helleńskim) w palestrze wyodrębnił się wyższy poziom - gimnazjum. Następujące po nim etapy edukacji również przesycone były treściami z zakresu aktywności fizycznej, w tym szczególnie efebia - okres od 17/18 do około 20 roku życia poświęcony przygotowaniu do służby wojskowej, właściwemu szkoleniu wojskowemu (w przypadku Spartan właściwa służba wojskowa trwała od 20 do 30 roku życia). Dla Ateńczyków efebia stanowiła właściwe szkolenie wojskowe i do bitwy pod Cheroneą w 338 roku była dobrowolna a jednocześnie wysoko ceniona, traktowana jako obowiązek obywatelski 
Gimnastycznego „Sokół”. Jako praktycy były to osoby najlepiej zorientowane w ćwiczeniach fizycznych, ich technice wykonania i metodyce nauczania, ponadto sprawne fizycznie i ideowo zaangażowane w działalność związaną z upowszechnianiem aktywności fizycznej.

Innego rodzaju ośrodkiem przygotowania nauczycieli do zajęć fizycznych stała się Akademia Krakowska, gdzie w 1893 roku przy Wydziale Lekarskim utworzono 2-letni „Kurs Naukowy dla Kandydatów na Nauczycieli Gimnastyki w Szkołach Średnich i Seminariach Nauczycielskich". Kurs ten adresowany był do studentów pragnących - obok zasadniczego kierunku specjalizacji studiów - uzyskać uprawnienia do nauczania wychowania fizycznego. Zajęcia obejmowały anatomię, fizjologię, dietetykę, teorię, metodykę i historię kultury fizycznej oraz ćwiczenia praktyczne. W 1913 roku Kurs został przekształcony w 2-letnie Studium Wychowania Fizycznego, a następnie, w 1927 roku, w 3-letnie Studium Wychowania Fizycznego przy Wydziale Lekarskim UJ.

Trzecim ośrodkiem kształcenia specjalistów dla kultury fizycznej był założony w 1892 roku Zakład Gimnastyki Szwedzkiej, Leczniczej, Zdrowotnej i Masażu dla Kobiet i Dzieci Heleny Kuczalskiej², gdzie od 1900 roku prowadzone były kursy dla kandydatów na nauczycieli gimnastyki, a od 1906 działała Warszawska Szkoła Gimnastyki Szwedzkiej i Masażu - pierwsza i jedyna w Królestwie Polskim instytucja kształcąca pedagogów w zakresie wychowania fizycznego.

Rola pioniera w zakresie kształcenia wychowawców fizycznych w odrodzonej, wolnej Polsce przypada, za sprawą Eugeniusza Piaseckiego (1872-1947)3, Uniwersytetowi Poznańskiemu, gdzie już w 1919 roku powstała Katedra Teorii Wychowania Fizycznego i Higieny Szkolnej przy Wydziale Filozoficznym, a następnie w 1922 - Studium Wychowania Fizycznego przy Wydziale Lekarskim Uniwersytetu.

Główna polska uczelnia kształcąca dla potrzeb wychowania fizycznego i sportu rozpoczęła swoją działalność w listopadzie 1929 roku w Warszawie na Bielanach. Centralny Instytut Wychowania Fizycznego (CIWF) był realizacją jednej z uchwał Sejmu Nauczycielskiego obradującego w dniach 14-17 IV 1919 roku. W odniesieniu do kształcenia nauczycieli wychowania fizycznego brzmiała ona: „zjazd uznaje, że przy każdym uniwersytecie powinno być utworzone studium wychowania fizycznego oparte o osobną katedrę wychowania fizycznego, a w stolicy państwa powinien powstać główny instytut wychowania fizycznego celem kształcenia kierowników wychowania fizycznego [...] kierownicy ci powinni, co do poziomu wykształcenia i stanowiska, stać na równi z innymi nauczycielami i móc wykładać także inny przedmiot szkolny".

2 Helena Kuczalska Prawdzic (1854-1927) - pedagog, pionierka wychowania fizycznego i sportu kobiet w Polsce, absolwentka Centralnego Królewskiego Instytutu Gimnastycznego w Sztokholmie, działaczka Ogrodów Gier i Zabaw Ruchowych im. W.E. Raua, założycielka "Grażyny” - pierwszej samodzielnej organizacji gimnastycznej (stowarzyszenia sportu) kobiet, współzałożycielka Warszawskiego Klubu Wioślarek, działaczka międzynarodowego ruchu wychowania fizycznego kobiet.

Syn Wenantego, jednego z założycieli Towarzystwa Gimnastycznego „Sokół” na ziemiach polskich (1867), autora pierwszego podręcznika do ćwiczeń fizycznych Słownictwo gimnastyczne (1867), teoretyk wychowania fizycznego, dzięki któremu osiągnęło ono rangę dyscypliny naukowej. 
Kulisy powstania Instytutu świadczą o wielkiej determinacji najwyższych władz ówczesnego państwa polskiego w budowaniu szkolnictwa wyższego dla potrzeb kultury fizycznej. Z formalną inicjatywą miał wystąpić ppłk Władysław Osmolski ${ }^{4}$, na pierwszym posiedzeniu Rady Naukowej Wychowania Fizycznego pod przewodnictwem Marszałka Józefa Piłsudskiego. Wobec spodziewanego oporu niektórych członków Rady w stosunku do koncepcji centralizacji kształcenia najwyżej kwalifikowanych kadr w stolicy kraju, decyzja o utworzeniu (budowie obiektów) wyższej szkoły zawodowej, kształcącej nauczycieli wychowania fizycznego na potrzeby szkolnictwa i wojska zapadła w 1927 roku w sposób nie w pełni formalny i typowy dla tamtych czasów. Najlepiej oddaje to zapis z aktu erekcyjnego z 2 grudnia 1928 roku, informujący, że „W 10-tą rocznicę Niepodległości [...] stanęły mury Centralnego Instytutu Wychowania Fizycznego powołanego do życia wolą i decyzją Pierwszego Marszałka Polski Józefa Piłsudskiego, aby niezmożony był duch i siła fizyczna Narodu" (Dudek, 2004, s. 124-128)5. Budowę rozpoczęto w następnym roku, a w listopadzie 1929 roku zainaugurowano pierwszy rok studiów. W 1938 roku Centralny Instytut Wychowania Fizycznego został przekształcony w wojskową szkołę akademicką pod nazwą Akademia Wychowania Fizycznego Józefa Piłsudskiego w Warszawie ${ }^{6}$.

Kształcenie kadr dla wychowania fizycznego w Polsce międzywojennej realizowane było $w$ trzech ośrodkach akademickich: centralnej uczelni kształcącej „kierowników wychowania fizycznego" w Warszawie, na Uniwersytecie Jagiellońskim i Uniwersytecie Poznańskim, w których funkcjonowały studia wychowania fizycznego, stanowiąc modelowe - niedoścignione do dnia dzisiejszego - rozwiązanie łączenia studiów z zakresu różnych dyscyplin naukowych ze studiami wychowania fizycznego. System ten wydatnie dopełniały, kształcące dla szkolnictwa podstawowego, seminaria nauczycielskie, a od 1932 roku licea pedagogiczne.

Po II wojnie światowej szeroko rozumiana kultura fizyczna, a więc i kształcenie na jej potrzeby specjalistów, stała się jednym z priorytetów „nowego socjalistycznego państwa". Podjęto tworzonie szkolnictwa średniego i wyższego dla

4 Ppłk Władysław Osmolski (1883-1935), lekarz i teoretyk wychowania fizycznego, następca Waleriana Sikorskiego na stanowisku komendanta, działającej od 1921 roku w Poznaniu, Centralnej Wojskowej Szkoły Gimnastyki i Sportów.

5 Dodać należy, że dokonało się to dzięki ścisłej współpracy najbliższego Marszałkowi grona oficerów ze wspomnianym ppłk. Osmolskim i płk. Ulrychem na czele. Płk Ulrych był dyrektorem Państwowego Urzędu Wychowania Fizycznego i Przysposobienia Wojskowego, który funkcjonował w obrębie Ministerstwa Obrony Narodowej od 1927 roku i był drugą po powstałej w 1919 roku Państwowej Radzie Wychowania Fizycznego i Kultury Cielesnej (organie doradczym dwu ministerstw: Zdrowia oraz Wyznań Religijnych i Oświecenia Publicznego), instytucją świadczącą o randze nadawanej sprawom wychowania fizycznego przez ówczesne państwo polskie.

6 Stało się to na mocy specjalnej ustawy z dnia 23 sierpnia 1938 roku o Akademii Wychowania Fizycznego Józefa Piłsudskiego w Warszawie. Pierwsza zmiana nazwy uczelni na "Centralny Instytut Wychowania Fizycznego im. Pierwszego Marszałka Polski Józefa Piłsudskiego” miała miejsce w 1935 roku po śmierci Marszałka, na wniosek pracowników i Rady Naukowej Wychowania Fizycznego. Od roku 1949 (Dekret Rady Ministrów z 27 lipca 1949) do 1990 uczelnia nosiła nazwę Akademii Wychowania Fizycznego im. gen. broni Karola Świerczewskiego, po czym uchwałą Sejmu z 8 czerwca 1990 przywrócona zostaje nazwa z 1938 roku - Akademia Wychowania Fizycznego Józefa Piłsudskiego w Warszawie. 
eliminacji olbrzymiego deficytu specjalistów wychowania fizycznego, jaki powstał w wyniku i po Il wojnie światowej. Rozporządzeniem Rady Ministrów z dnia 5 lipca 1950 roku (Dz. U. z 1950 r., nr 29, poz. 273), funkcjonujące na uniwersytetach Poznania, Wrocławia i Krakowa jednostki - Studia Wychowania Fizycznego - przekształcono w samodzielne Wyższe Szkoły Wychowania Fizycznego, w miejsce których powołano następnie Akademie Wychowania Fizycznego.

Istniejące od 1893 roku Studium Wychowania Fizycznego na Uniwersytecie Jagiellońskim zostało przekształcone w 1950 w Wyższą Szkołę Wychowania Fizycznego, a w 1972, w Akademię Wychowania Fizycznego im. Bronisława Czecha w Krakowie.

Studium Wychowania Fizycznego przy Wydziale Lekarskim Uniwersytetu Poznańskiego w 1950 roku zostało przekształcone w samodzielną Wyższą Szkołę Wychowania Fizycznego, a w 1972 roku, w Akademię Wychowania Fizycznego, której w 1981 roku nadano imię Eugeniusza Piaseckiego. Studium Wychowania Fizycznego Uniwersytetu i Politechniki Wrocławskiej zostało przekształcone w 1950 roku w Wyższą Szkołę Wychowania Fizycznego, a w 1972 roku, w Akademię Wychowania Fizycznego we Wrocławiu.

Niemal identycznie przedstawia się historia dwóch kolejnych uczelni wychowania fizycznego - w Katowicach i Gdańsku-Oliwie. Wyższa Szkoła Wychowania Fizycznego w Katowicach powstała w 1970 roku na podstawie - funkcjonującego od 1957 roku - Studium Nauczycielskiego Wychowania Fizycznego, a wcześniej - istniejącego od 1952 roku, Technikum Wychowania Fizycznego w Katowicach. W 1979 roku Wyższa Szkoła Wychowania Fizycznego w Katowicach została przekształcona w Akademię Wychowania Fizycznego im. Jerzego Kukuczki w Katowicach. W Gdańsku-Oliwie, funkcjonujące od 1952 roku, Technikum Wychowania Fizycznego przekształcone zostało w 1957 roku w Studium Nauczycielskie Wychowania Fizycznego, a następnie w roku 1969 w Wyższą Szkołę Wychowania Fizycznego (od 1973 WSWF im. Jędrzeja Śniadeckiego). W 1981 roku WSWF została przemianowana na Akademię Wychowania Fizycznego im. Jędrzeja Śniadeckiego, a w 2001 roku - Akademię Wychowania Fizycznego i Sportu im. Jędrzeja Śniadeckiego.

W latach 70. uczelnie w Warszawie i Poznaniu utworzyły jednostki zamiejscowe. W roku 1970 w Białej Podlaskiej powstała filia AWF w Warszawie (wcześniej, od 1969 roku, Wyższe Studium Nauczycielskie, będące filią UMCS w Lublinie), przekształcona w 2001 w Zamiejscowy Wydział Wychowania Fizycznego AWF w Warszawie, w 2010 - Wydział Wychowania Fizycznego i Sportu w Białej Podlaskiej, a od 2014 - Akademię Wychowania Fizycznego Józefa Piłsudskiego Filia w Białej Podlaskiej. Z kolei w roku 1971 w Gorzowie Wielkopolskim powstała filia AWF w Poznaniu, w 1984 - Zamiejscowy Wydział Kultury Fizycznej, w 1993 - Instytut Wydziału Wychowania Fizycznego, a od 2003 - Zamiejscowy Wydział Kultury Fizycznej AWF w Poznaniu w Gorzowie Wielkopolskim.

Na mapie instytucji kształcących specjalistów wychowania fizycznego w tamtym czasie w Polsce brakuje Łodzi - drugiego co do liczby mieszkańców miasta i ważnego przemysłowego regionu. Początki tego kształcenia nastąpią dopiero w latach 80. 


\section{Cel badań i analiz}

Przeprowadzone badania, polegające na kwerendzie zasobów archiwalnych dziekanatu Wydziału Nauk o Wychowaniu Uniwersytetu Łódzkiego z wykorzystaniem pomocy w postaci udostępnienia informacji przez zatrudnione tam od początku istnienia Wydziału osób, jak również zgromadzonego materiału dokumentacyjnego (dokumenty, regulacje prawne i doniesienia prasowe), zmierzały do przygotowania monografii kształcenia wychowawców fizycznych.

Praca poświęcona jest swoistej systematyzacji dokonań w zakresie kształcenia kadr kultury fizycznej na przestrzeni ostatnich 30 lat w Łodzi. Zawiera wykazy oraz dane liczbowe odnośnie do absolwentów (Wychowania Fizycznego i Zdrowotnego oraz Pedagogiki Kultury Fizycznej i Zdrowotnej) kończących studia w kolejnych latach na Wydziale Nauk o Wychowaniu Uniwersytetu Łódzkiego. Analizy koncentrują się więc na okresie od 1991 roku - tj. od momentu powstania Wydziału Nauk o Wychowaniu, który przejął kształcenie specjalistów kultury fizycznej w Łodzi od wcześniej funkcjonujących instytucji.

We wstępie do tak założonego planu prezentacji dokonań w zakresie kształcenia wychowawców fizycznych $w$ Łodzi postawiono jego genezę - w tym ważne momenty, wydarzenia i fakty istotne, czy wręcz decydujące dla zaistnienia i dalszego funkcjonowania kształcenia specjalistów kultury fizycznej w Łodzi. W opracowanym materiale odniesiono się także do twórców sukcesu, jakim niewątpliwie było zbudowanie systemu kształcenia kadr dla kultury fizycznej w regionie łódzkim.

Spośród osób zaangażowanych w działania na rzecz edukacji kolejnych pokoleń specjalistów wychowania fizycznego i sportu przybliżono dokonania trzech postaci: doc. dra Kajetana Hądzelka, prof. dra hab. Zygmunta Jaworskiego i prof. dr hab. Zofii Żukowskiej. To osoby, którym zawdzięczamy zainicjowanie kształcenia wychowawców fizycznych, wyznaczenie jego kierunku i jakości realizacji, osoby bez których trudno byłoby wyobrazić sobie wykształcenie setek nauczycieli wychowania fizycznego, uczących w szkołach regionu łódzkiego, a także instruktorów, trenerów i pozostałych specjalistów zatrudnionych w instytucjach kultury fizycznej w regionie łódzkim.

\section{Kształcenie kadr kultury fizycznej w Łodzi - początki i rozwój ${ }^{7}$}

Ponad 30 lat temu, w listopadzie 1984 roku, rozpoczęło się, trwające do dzisiaj, systematyczne kształcenie wychowawców fizycznych - nauczycieli wychowania fizycznego i trenerów. Wcześniejsze inicjatywy kształcenia wysoko kwalifikowanych specjalistów w tej dziedzinie, podyktowane wielkimi potrzebami w szkolnictwie, jak również w stowarzyszeniach i klubach sportowych w regionie łódzkim w tym zakresie, miały charakter epizodyczny. Odbywały się w ramach tzw. punktów konsultacyjnych. Były to placówki pomagające w studiowaniu

\footnotetext{
7 Wystąpienie Autora na Konferencji.
} 
studentom studiów zaocznych warszawskiej AWF pochodzącym z miasta i okolic Łodzi, w zakresie opanowania przedmiotów praktycznych gimnastyki (2 godziny) i pływania (1 godzina) oraz wybranych teoretycznych (4 godziny) przez jeden dzień w tygodniu. W Łodzi taki punkt konsultacyjny funkcjonował już w latach 50 . (1952-1958) przy Wojewódzkim Komitecie Kultury Fizycznej. Działalność punku konsultacyjnego została wznowiona w latach 70. (1970-1979) na mocy porozumienia pomiędzy AWF w Warszawie i Prezydium Rady Narodowej oraz Komitetem Kultury Fizycznej i Turystyki w Łodzi.

Od 1973 roku po reformie studiów wychowania fizycznego, umożliwiającej kształcenie w trybie 4-letnich magisterskich studiów zaocznych na kierunkach nauczycielskim, trenerskim i rekreacji, rozpoczęło się kształcenie studentów pierwszych dwóch roczników na kierunku nauczycielskim i trenerskim (od 1976 roku także studentów III roku studiów na kierunku nauczycielskim) na miejscu, w Łodzi. Do realizacji zajęć wykorzystywano obiekty Akademii Medycznej, Uniwersytetu Łódzkiego, a także Technikum Chemicznego przy ulicy Tamka, Pałacu Młodzieży przy ulicy Moniuszki, Akademickiego Związku Sportowego przy ulicy Styrskiej i Łódzkiego Klubu Sportowego. Kadrę dydaktyczno-naukową stanowili pracownicy AWF w Warszawie oraz pracownicy wymienionych instytucji - profesorowie Akademii Medycznej i Uniwersytetu Łódzkiego, trenerzy i nauczyciele wychowania fizycznego z miejscowych klubów i szkół

Mimo iż kontynuacja studiów na IV roku na kierunku nauczycielskim oraz III i IV na kierunku trenerskim odbywała się w warszawskiej AWF, to był to znaczący krok w usamodzielnianiu się Łodzi jako ośrodka akademickiego w obszarze kultury fizycznej. W latach 1973-1979 w łódzkim punkcie konsultacyjnym studiowały łącznie 834 osoby. Kierownikami punktu konsultacyjnego byli mgr Janusz Nowacki (1970-1973), dr Tadeusz Łobożewicz (1973-1974) i dr Lechosław Skorupski (1975-1979).

Kolejny etap akademickiego kształcenia specjalistów dla kultury fizycznej w Łodzi - kształcenia, które trwa do dnia dzisiejszego, rozpoczął się w 1984 roku.

Po wcześniejszych uzgodnieniach i działaniach na szczeblu władz miasta Łodzi, władz Akademii Wychowania Fizycznego w Warszawie oraz Głównego Komitetu Kultury Fizycznej i Sportu (GKKFiS), 12(15) listopada 1984 roku (senat AWF decyzję podjął 13 września 1984 roku), rozpoczął działalność Zespół Zakładów Dydaktyczno-Naukowych w Łodzi - zamiejscowa placówka Wydziału Wychowania Fizycznego warszawskiej AWF.

Kierownictwo placówki, która szybko zyskała nazwę „łódzkiej AWF”, objął w randze pełnomocnika Rektora AWF ds. ZZDN, prodziekan Wydziału Wychowania Fizycznego AWF Warszawa, doc. dr Kajetan Hądzelek - wielki przyjaciel Łodzi i łodzianin, jak sam siebie nazywał. Człowiek, który tej deklarowanej przyjaźni wówczas, i w następnych latach, będzie nadawał realny kształt.

W listopadzie 1984 roku pierwszych 57 studentów, którzy zdali egzaminy wstępne na inne uczelnie wychowania fizycznego w kraju (głównie AWF

8 Informacje na ten temat zawiera Księga pamiątkowa Akademii Wychowania Fizycznego im. Józefa Piłsudskiego w Warszawie 1929/1930-2009/2010, opracowana pod redakcją doc. Kajetana Hędzelka i dra Krzysztofa Zuchorę, opublikowane w 2010 roku. 
w Warszawie), złożyło ślubowanie i rozpoczęło studia w Zespole Zakładów Dydaktyczno-Naukowych AWF Warszawa z siedzibą w Łodzi. W kształcenie studentów z Łodzi i regionu łódzkiego zaangażowały, się poza pracownikami naukowo-dydaktycznymi Wydziału Wychowania Fizycznego AWF w Warszawie, Wojskowa Akademia Medyczna i Uniwersytet Łódzki, udostępniając swoje obiekty i kadrę naukowo-dydaktyczną, oraz specjaliści, trenerzy i nauczyciele wychowania fizycznego z terenu Łodzi. Zajęcia realizowane były na obiektach specjalistycznych, w klubach sportowych, obiektach WAM i UŁ i własnym budynku przy ulicy Rudzkiej 56. Dla studentów studiujących w trybie dziennym zarezerwowano akademiki Politechniki Łódzkiej, a dla słuchaczy zaocznych na czas sesji hotel w Hali Sportowej.

W drugim roku funkcjonowania ZZDN (1985) studia podjęło 71 studentów studiów stacjonarnych i 62 na studiach zaocznych. Łącznie z drugim rocznikiem było to już 189 osób. Na inauguracji obecne było liczne grono wykładowców AWF w Warszawie z rektorem, prof. drem hab. Tadeuszem Ulatowskim. Świadczy to o wadze, jaką przywiązywały władze tej uczelni do funkcjonowania i rozwoju swojej najmłodszej jednostki jaką była „tódzka AWF”.

Trzecia inauguracja, w 1986 roku, zgromadziła 75 studentów pierwszego rocznika oraz słuchaczy 2 i 3 roku - łącznie 200 osób na stacjonarnych i 100 na studiach zaocznych. Zajęcia realizowało 60 nauczycieli, studiowało zaś wielu znanych sportowców z regionu łódzkiego. Wzorem lat ubiegłych na inauguracji obecna była liczna reprezentacja warszawskiego AWF, z prorektorem doc. drem hab. Stefanem Piliczem, dziekanami i prodziekanami Wydziału Wychowania Fizycznego. Przybyłych na inaugurację powitał prodziekan Wydziału doc. dr Kajetan Hądzelek, a doc. dr hab. Ryszard Przewęda wygłosił wykład inauguracyjny na temat „Wychowanie fizyczne w życiu człowieka”.

Czwarty rok działalności „łódzkiej AWF” (Zespołu Zakładów Dydaktyczno-Naukowych) w 1987 roku zainaugurował komplet, wszystkie cztery roczniki studentów - łącznie 267 osób na studiach stacjonarnych i 124 zaocznych. Swój pierwszy rok studiów rozpoczęło 90 studentów. Rok akademicki 1987-1988 jest jednocześnie ostatnim dla 48 studentów (w tym 12 kobiet), którzy jako pierwsi, cztery lata wcześniej rozpoczynali studia. Wśród pierwszych absolwentów kończących „tódzką AWF” z tytułem magistra są późniejsi pracownicy Katedry Wychowania Fizycznego i zdrowotnego.

Niemal od momentu uruchomienia Zespołu Zakładów Dydaktyczno-Naukowych trwały zabiegi poszerzenia działalności przez nadanie mu odpowiedniej rangi w wymiarze formalnym, w kierunku większego usamodzielnienia. Zrozumiałe aspiracje środowiska łódzkiego były zgodne z działaniami władz AWF w Warszawie. W 1988 roku Senat tej uczelni podjął decyzję o przekształceniu Zespołu Zakładów Dydaktyczno-Naukowych w Zamiejscowy Wydział Wychowania Fizycznego w Łodzi. Ostatecznie Zespół Zakładów Dydaktyczno-Naukowych w 1990 uzyskał rangę Instytut Wychowania Fizycznego i Sportu AWF Warszawa w Łodzi. Dyrektorem Instytutu został doc. dr Kajetan Hądzelek.

W siódmym roku działalności (1990-1991) w łódzkiej AWF (oficjalna nazwa Instytut Wychowania Fizycznego i Sportu AWF w Warszawie) studiowało 300 osób w trybie dziennym i 196 osób zaocznie (łącznie około 500 słuchaczy). Studia 
rozpoczęło 98 studentów, wcześniej z tytułem magistra ukończyło kolejnych 43 studentów studiów stacjonarnych i 38 pięcioletniego studium zaocznego. Łącznie do tego momentu uczelnię ukończyły trzy roczniki studentów - prawie 150 osób, z których $90 \%$ podjęło pracę w zawodzie (jako nauczyciele wychowania fizycznego w łódzkich szkołach).

Rok 1991 jest był ostatnim rokiem funkcjonowania tej zamiejscowej placówki warszawskiej AWF.

Na mocy wcześniejszych porozumień ${ }^{9}$, uchwałą Senatu UŁ z dnia 13 września 1991, a następnie zarządzeniem Rektora z dnia 30 września 1991, z dniem 1 X 1991 powołany został Wydział Nauk o Wychowaniu. Współtworzą go katedry pedagogiczna i psychologiczna wydziału Filozoficzno-Historycznego Uniwersytetu Łódzkiego i łódzka filia AWF w Warszawie (Instytut Wychowania Fizycznego i Sportu AWF w Warszawie). Z tą chwilą skończył się etap patronatu warszawskiej Akademii Wychowania Fizycznego nad kształceniem wychowawców fizycznych dla Łodzi i regionu a rozpoczął okres samodzielności akademickiej Łodzi w kształceniu kadr kultury fizycznej dla łódzkiego środowiska. Od tej pory kształcenie to będzie realizowane w Katedrze Wychowania Fizycznego i Zdrowotnego na Wydziale Nauk o Wychowaniu ${ }^{10}$.

Nazwę i strukturę nowo powstałej jednostki zawdzięczamy prof. drowi hab. Zygmuntowi Jaworskiemu, który objął jej kierownictwo jako prodziekan Wydziału Nauk o Wychowaniu. To nazwa prorocza. Wyznaczy ona trend w kulturze fizycznej i edukacji. Wychowanie do zdrowia jako składowa kształcenia młodych pokoleń Polaków wejdzie na stałe do systemu polskiej edukacji i kształcenia akademickiego. Wychowanie zdrowotne, edukacja zdrowotna, promocja zdrowia, znajdzie się też w nazwach niezliczonych jednostek na niemalże wszystkich uczelniach w kraju (także politechnicznych).

Początek samodzielnego kształcenia wysoko kwalifikowanych kadr dla kultury fizycznej w ramach Wydziału Nauk o Wychowaniu na Uniwersytecie Łódzkim nie oznaczał końca współpracy ze środowiskiem naukowym warszawskiej Akademii Wychowania Fizycznego (zarówno doc. Kajetan Hądzelek, jak i prof. Zygmunt Jaworski są pracownikami tej uczelni) - nabrała ona nowego wymiaru.

Nowo powstała jednostka - Katedra Wychowania Fizycznego i Zdrowotnego - nie posiadała własnej kadry. Pracę nad przygotowaniem zespołu pracowników

9 Między Wojewodą Łódzkim Waldemarem Bohdanowiczem, Miastem Łódź reprezentowanym przez Prezydenta M. Łodzi Grzegorza Palkę, wiceprezydent Elżbietę Hibner oraz Rektorem UŁ prof. drem hab. Michałem Seweryńskim, Rektorem AWF im. Józefa Piłsudskiego w Warszawie - prof. drem hab. Zbigniewem Krawczykiem.

10 Strukturę wydziału stanowią: Katedra Dydaktyki; Katedra Historii Wychowania i Pedeutologii; Katedra Pedagogiki Przedszkolnej i Wczesnoszkolnej; Katedra Pedagogiki Specjalnej; Katedra Pedagogiki Społecznej; Katedra Teorii Wychowania z Zakładem Oświaty Dorosłych; Katedra Wychowania Muzycznego z Zespołem Dydaktycznym Wychowania Muzycznego i Zakładem Folklorystyki; Katedra Psychologii z czterema zakładami: Psychologii Klinicznej i Osobowości, Psychologii Wychowawczej i Rozwojowej, Psychologii Ogólnej, Psychologii Społecznej; Katedra Wychowania Fizycznego i Zdrowotnego z trzema zakładami: Teoretycznych Podstaw Wychowania Fizycznego i Zdrowotnego, Technik i Metodyki Wychowania Zdrowotnego, Technik i Metodyki Aktywności Ruchowej; Studium Wychowania Fizycznego i Sportu. 
naukowych podjęła prof. dr hab. Zofia Żukowska - wielka osobowość, wspaniały wychowawca nauczycieli, osoba, której Pracownia Wychowania Fizycznego i Zdrowotnego jak i cały młody jeszcze wtedy Wydział Nauk o Wychowaniu bardzo wiele zawdzięcza. Efektem tej blisko 10-letniej pracy było wychowanie - wykształcenie kadry nauczycieli akademickich doktorów (jest promotorem doktoratów istotnej części kadry naukowo-dydaktycznej jednostki). Profesor Żukowska zmarła w listopadzie 2013 roku, ale obecna jest nadal w osobach swoich wychowanków, do których autor miał wówczas szczęście, a dziś zaszczyt, się zaliczać.

Prezentacji dokonań w zakresie efektów kształcenia wychowawców fizycznych i pozostałych specjalistów z obszaru kultury fizycznej w Katedrze Wychowania Fizycznego i Zdrowotnego na Wydziale Nauk o Wychowaniu nadano formę wykresów przedstawiających liczbę wypromowanych magistrów i licencjatów z podziałem na różne rodzaje studiów, jakie były realizowane od początku, tj. od 1991 roku do dnia dzisiejszego.

Umowa (porozumienie) zawarte pomiędzy władzami województwa łódzkiego i miasta Łódź oraz władzami Uniwersytetu Łódzkiego i Akademii Wychowania Fizycznego w Warszawie zawiera dwa aneksy: o siedzibie przyszłej Katedry Wychowania Fizycznego i Zdrowotnego (zobowiązanie władz województwa i miasta o przydzieleniu na potrzeby Katedry odpowiednich budynków nie zostało zrealizowane) i o studiujących studentach:

Studenci IV i III roku kończą studia według programu AWF i na AWF.

Studenci II roku otrzymują propozycję studiowania na UŁ zgodnie z planem i programami dla Katedry Wychowania Fizycznego i Zdrowotnego z założeniem wyrównania różnic programowych na II i III roku lub mogą kontynuować studia zgodnie z planem i programami dla AWF i po roku na AWF w Warszawie.

Studenci przyjęci na I rok studiów w Instytucie Wychowania Fizycznego i Sportu studiują zgodnie z planem i programami dla Katedry Wychowania Fizycznego i Zdrowotnego, a jeśli nie są zainteresowani, przechodzą na AWF do Warszawy po roku.

Studenci studiów zaocznych kontynuują studia zgodnie z planem i programami dla AWF i po roku na AWF w Warszawie w trybie zaocznym.

\section{Kształcenie kadr kultury fizycznej w Łodzi - analiza dokonań}

Analizując rozwój kształcenia kadr kultury fizycznej (podejmowane w tym zakresie inicjatywy) na potrzeby regionu Łódzkiego, można wyodrębnić następujące etapy:

- etap I - lata 1970-1979 (1973-1979) - punkt konsultacyjny przy Komitecie Kultury Fizycznej w Łodzi;

- etap II - lata 1984-1991 - „łódzka AWF” (Zespół Zakładów Dydaktyczno-Naukowych / Instytut Wychowania Fizycznego i Sportu warszawskiej AWF w Łodzi); 
- etap III - lata 1991-2015 - Katedra Wychowania Fizycznego i Zdrowotnego (obecnie Pracownia Wychowania Fizycznego i Zdrowotnego).

Trwające od 1991 roku kształcenie wychowawców fizycznych w Katedrze Wychowania Fizycznego i Zdrowotnego, a obecnie Pracowni Wychowania Fizycznego i Zdrowotnego, realizowane było w następujących systemach studiów:

- 5-letnie studia magisterskie - stacjonarne,

- 5-letnie studia magisterskie - niestacjonarne,

- rok licencjacki,

- studia II stopnia (uzupełniające magisterskie) - niestacjonarne,

- studia I stopnia (licencjackie) - stacjonarne,

- studia I stopnia (licencjackie) - niestacjonarne,

- studia II stopnia (magisterskie) - stacjonarne.

Kształcenie w ramach 5-letnich studiów magisterskich w trybie stacjonarnym realizowane było od początku istnienia Katedry Wychowania Fizycznego i Zdrowotnego od 1991 do 2011 roku. Od 1995 roku przez kolejne siedemnaście lat studia te z tytułem magistra ukończyło łącznie 1216 osób. Liczbę osób kończących studia w poszczególnych latach przedstawia rycina 1.

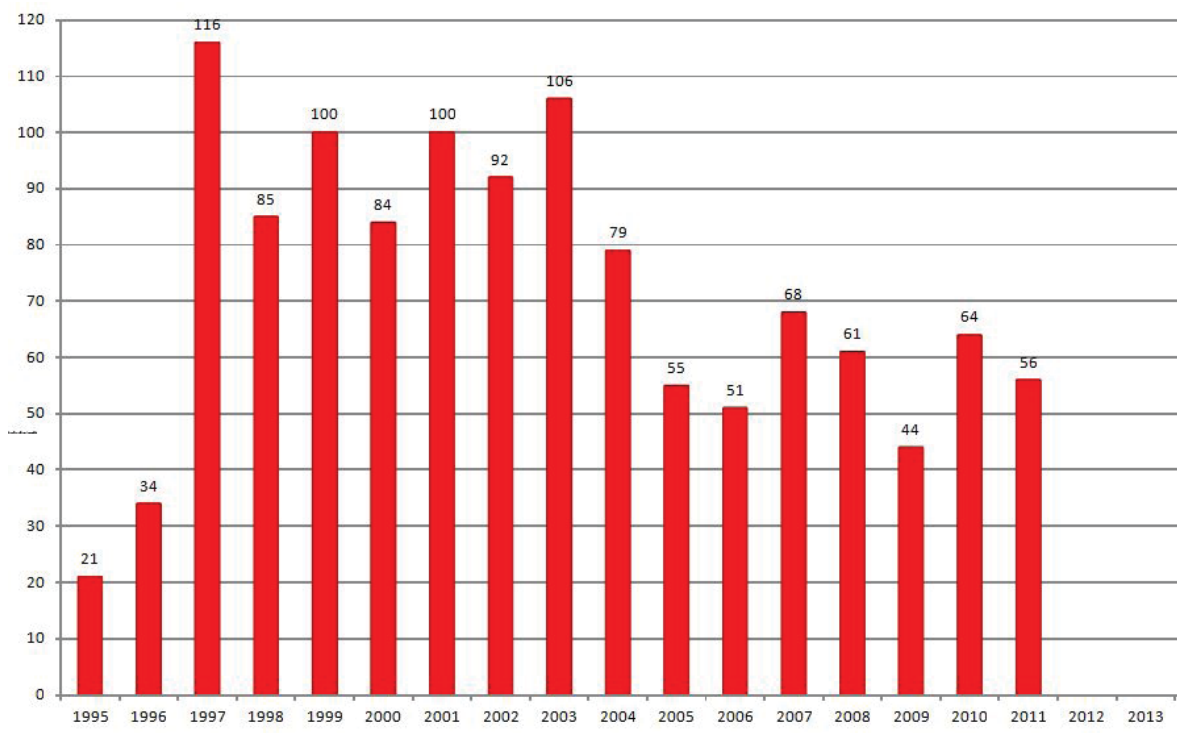

Rycina 1. Absolwenci 5-letnich studiów magisterskich Wychowania Fizycznego i Zdrowotnego oraz Pedagogiki Kultury Fizycznej i Zdrowotnej - dziennych (1216 osób)

Źródło: opracowanie własne.

W latach 2001-2009 tytuł magistra zdobyło także 2009 studentów studiujących równolegle w trybie niestacjonarnym (rycina 2 ).

W roku akademickim 1999/2000 w Katedrze Wychowania Fizycznego i Zdrowotnego podjęto kształcenie w ramach tzw. roku licencjackiego. Uczestnikami tych 


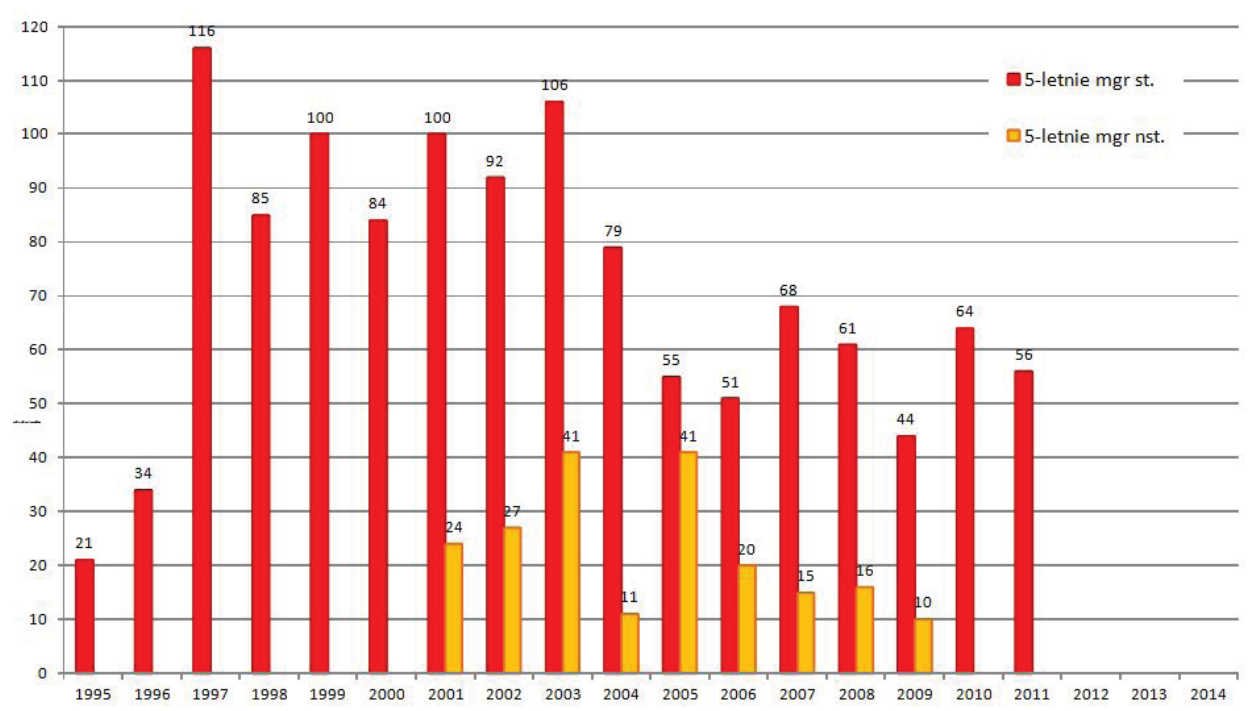

Rycina 2. Absolwenci 5-letnich studiów magisterskich Wychowania Fizycznego i Zdrowotnego oraz Pedagogiki Kultury Fizycznej i Zdrowotnej - dziennych i zaocznych $(1216+205)$

Źródło: opracowanie własne.

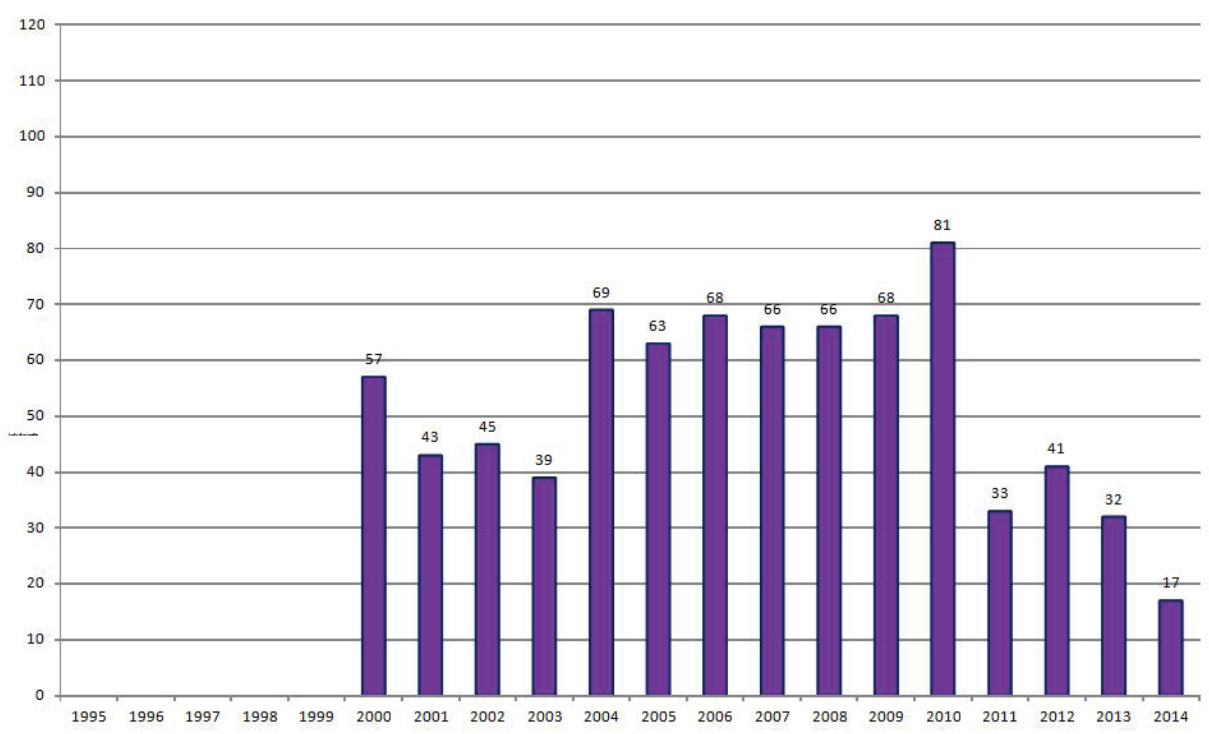

Rycina 3. Absolwenci roku licencjackiego - słuchacze Kolegiów Nauczycielskich w Łowiczu i w Zgierzu (788 osób)

Źródło: opracowanie własne. 
studiów byli słuchacze III rocznika Kolegiów Nauczycielskich w Zgierzu i w Łowiczu. Łącznie z tego trybu studiowania na przestrzeni 16 lat (ostatni rocznik ukończył studia w 2015 roku) skorzystało, uzyskując stopień licencjata, 788 osób (rycina 3). Łącznie z absolwentami rocznika 2015 ponad ośmiuset specjalistów, nauczycieli wychowania fizycznego wykształconych przez te ośrodki stanowi niezwykle istotny wkład w rozwój kultury fizycznej w regionie łódzkim.

Od roku 2010 studia w Pracowni Wychowania Fizycznego i Zdrowotnego kończą studenci studiujący w systemie dwustopniowym - trzyletnich licencjackich studiów I stopnia i dwuletnich uzupełniających studiów magisterskich II stopnia. Studia te ukończyło 326 licencjatów i 213 magistrów (rycina 4).

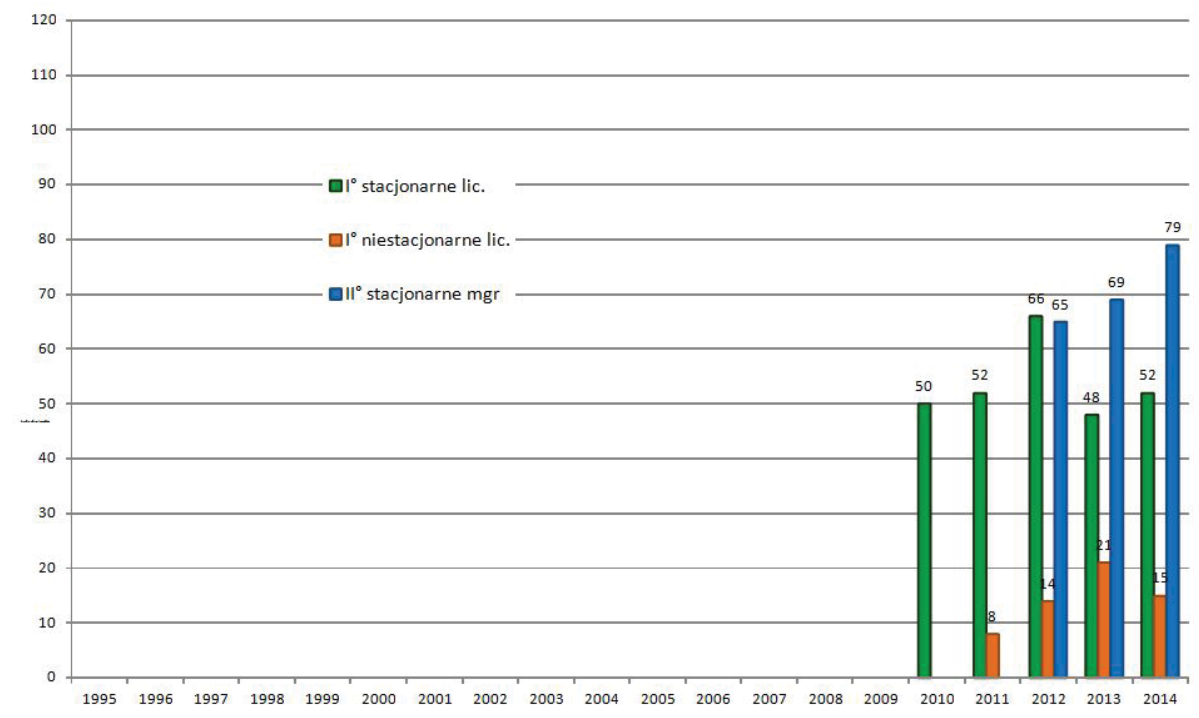

Rycina 4. Absolwenci Pedagogiki Kultury Fizycznej i Zdrowotnej studiów I stopnia - stacjonarnych i niestacjonarnych oraz II stopnia - stacjonarnych $(268+58+213)$

Źródło: opracowanie własne.

Działalność Katedry Wychowania Fizycznego następnie Pracowni Wychowania Fizycznego w latach 1991-2014 ujętą w liczbach kończących studia absolwentów z tytułem magistra i licencjata, poczynając od roku 1995, przedstawia rycina 5. 


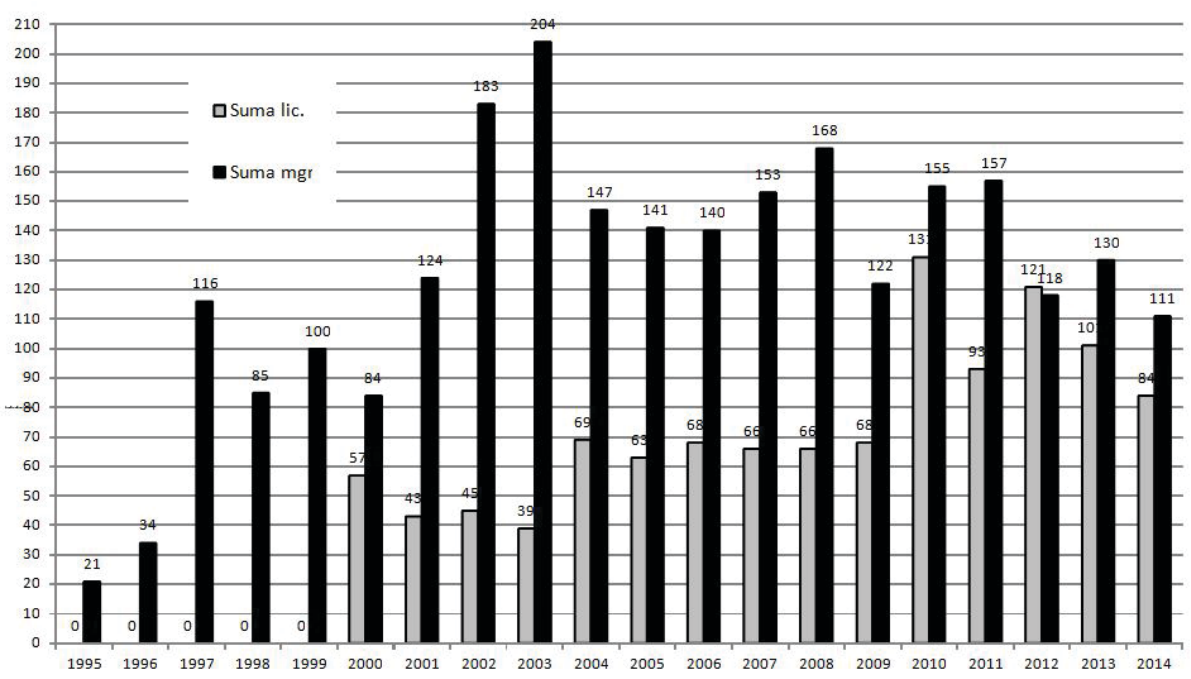

Rycina 5. Absolwenci Wychowania Fizycznego i Zdrowotnego oraz Pedagogiki Kultury Fizycznej i Zdrowotnej w Uniwersytecie Łódzkim - poziom licencjacki i magisterski (1114 + 2493)

Źródło: opracowanie własne.

\section{Podsumowanie}

Historia kształcenia specjalistów kultury fizycznej w Łodzi sięga lat $70 . \mathrm{XX}$ wieku. Pierwotnie realizowane w ramach tzw. Punktów konsultacyjnych warszawskiej AWF, stanowiło w całości formę działalności tej uczelni w nieodległym od stolicy mieście Łodzi, w dodatku o charakterze incydentalnym. Właściwą inaugurację kształcenia nauczycieli wychowania fizycznego $w$ Łodzi należy wiązać z utworzeniem w 1984 roku Zespołu Zakładów Dydaktyczno-Naukowych (przekształconego, na krótko w Instytut Wychowania Fizycznego i Sportu AWF Warszawa w Łodzi). Kształcenie to miało już charakter systematyczny i, pomimo pełnej zależności od warszawskiej AWF, w znacznym zakresie realizowane było siłami miejscowej kadry. Pełna samodzielność kształcenia specjalistów kultury fizycznej nastąpiła z chwilą utworzenia na Uniwersytecie Łódzkim Wydziału Nauk o Wychowaniu, a w jego ramach Katedry Wychowania Fizycznego i Zdrowotnego (obecnie Pracownia Wychowania Fizycznego i Zdrowotnego). Efekty działalności tej jednostki były przedmiotem niniejszego opracowania. Mają one postać zestawień liczby absolwentów kończących studia w różnym trybie, w poszczególnych latach - od 1995 do 2014. Łącznie jest to ponad 4500 osób (1114 licencjatów i 2493 magistrów). Obecnie, spośród nich rekrutuje się niemal w całości kadra pedagogiczna ze specjalnością wychowanie fizyczne, szkół w Łodzi i regionie. Wielu znalazło też zatrudnienie $w$ instytucjach kultury fizycznej i innych, poszukujących osób z wykształceniem wyższym w kulturze fizycznej. 


\section{Literatura}

Dudek D., 2004, Józef Piłsudski wobec problemu kultury fizycznej 1910-1935, Studia i Monografie, nr 26, Wydawnictwa AWF w Krakowie, Kraków.

Hądzelek K., Wroczyński R. (red.), 1968, Główne kierunki rozwoju i wychowania, Zakład Narodowy im. Ossolińskich, Wrocław-Warszawa-Kraków.

Kowieska U., 1994, Wybór źródeł i tekstów z historii kultury fizycznej i rehabilitacji, Wydawnictwo AWF we Wrocławiu, Wrocław.

Ławniczak P., 2010, Gimnastyka na przestrzeni dziejów, (w:) Wychowanie, opieka i edukacja w perspektywie historycznej i współcześnie, red. S. Lipiński, Wyższa Szkoła Edukacji Zdrowotnej i Nauk Społecznych, Łódź. 